今回のサマースクールほどアクティブなものは,私は, 初めて体験しました，その光景に私は，参加者のモチ ベーションの高さを見ると同時に，将来のブレイン． サイエンスへの希望を感じました。

講義内容に関しては，普段あまり聴くことができな い, 実験的側面からの話，特に，最新の実験デー夕を 非常に細かく聴くことができて,大変満足しています。 ただ，今回のサマースクールでは実験系の講義が多か ったように思います．欲を言えば，基本的な数理モデ ルや「理論を実験とどう結びつけるのか」といった観 点からの講義が聴きたかったと思います、私の個人的 な気持ちとしては，モデル・理論に対して，笑験系の 人がどのような印象を抱くのかという点に非常に関心 がありましたままた，理論に対して実験系の人と意見 を交わしたいと思っていたので，今回，理論的側面か らの話題が少なかったのは少し残念に思いました。

講義の他に, 参加してみて良かったと感じた点は, やはり，様々なバックグラウンドの人達と意見を交わ す事ができたことです，そして，自分とは違う様々な 研究について知ることができたと同時に，バックグラ ウンドの違う人に自身の研究を伝える難しさを知りま した．個人が普段取り組んでいる研究はごく限られた
範囲でしかありません，それだけでも，大きな意味を 持つのは確かですが，他分野との関連があってこそ， その意味はより大きなものとなるのだと思います．特 に, 脳科学研究というのは, 解剖学・生理学・工学を はじめとして，様々なアプローチが可能な領域です。 だからこそ，他分野とのコミュニケーションは必要不 可欠で，そのためには，いかに他分野（脳科学だけに とどまらず）の方にわかりやすく伝えるかということ が大切だと思います。サマースクールは，様々なバッ クグラウンドを持った人が自由に意見を交わすことの できる場所だと感じました，様々な方面からのアプロ 一千の融合という，いわば脳科学の理想の型が今回の サマースクールにあったのだと感じています。

今回のサマースクールに参加して，様ヶなバックグ ラウンドを持った方々と意見を交わせたことは，非常 に良い制激となりましたままたブレイン・サイエン スの未来に大いに貢献するであろう，たくさんの人と の出会いは一生の宝物になると思います。最後に，多 くの知識，そして，素晴しい出会いを与えてくれた NISS 関倸者の皆様にお礼を申し上げます。ありがと うございました。

\title{
NISS2003 に参加して
}

\section{奈良先端科学技術大学院大学 船 越 英 史}

私は今回初めて NISS に参加する機会に恵まれ，充 実した数日間を過ごした。今年の NISS では，大脳皮 質・海馬・大脳基底核といった脳の代表的領野の情報 処理機構に関する生理的な講義が多く，自分が普段研 究手法として用いている fMRI 実験よりもミクロなレ ベルでの実験アプローチと，その基盤となる考え方を 理解することで，より実際の脳に即した情報処理モデ ルを提案できるようになりたいと考え参加を決断し た. 実際の講義は常に活発な議論の伴う密度の高いも のであり，非常に刺激になるものであったＮISS 2003 では連日の講義に加えて, 講義内容と関連のあ る演習テーマの大杵がいくつか設定されており，その 内で演習グループ毎に自主的な問題設定と議論が行わ れた。演習は今年から MATLABや NEURON Simulator を用いた実習形式となっており個人的には 大変貴重な経験を得ることができた。

私の属した演習グループでは，海馬で見られる $\theta !$ ズムの情報処理的な機序について Jensen が 2001 年に 提案したモデルを基礎に，講義テーマの1つである海
馬に扮けるCA2 領域の役割について検討を行い， Jensen モデルの改良を試みた。 Jensen モデルでは Place cell の発火夕イミングと直線の経路想起につい て検討が行われているが，分岐のある経路想起を区别 できるようには作られていない。そこで，我々は CA2 領野に上乳頭対核からの投射があることが，CA3 から CA1にかけての線維連絡に選択的な学㥜効果を 与えている可能性を検討し，モデルへの組み込みにつ いて議論した．仮説モデルについて議論しているうち に，理解していたつもりであった Jensen モデルの理 解が不十分であったことや, 生理学的に妥当なモデル を主張することの困難さが浮き彫りになり，議論の大 切さを痛感するものであった。最初に妄想から膨らま せた壮大なモデルは検討を重ねるうちに小さくなり， 最終的に出来上がったものは稚拙なものであったと思 うが，自分ひとりだけではなかなか取っ掛かりのつか みにくいものが, グループメンバーとのコミュニケー ションを通じて形になっていくプロセスは，大きな経 験であったと思う。 
いくらか残念であったことは，講義日程の関係から か演習時間が夜に設定されて抒り，議論が白熱してく る夜中には次の日の講義のために途中で打ち切らなけ ればならないことが多々あったことである。 NISS2003 での講義は系統だったものであり非常に充 実した内容であったと思うが，実際的な問題に対して 意見交換から解決を求めようとする行為を短期間で行 えることもこのスクールの重要な意義であると思うの で, 演習の時間にももう少し時間を割いてほしいと思 う.

現在，私は脳の学習機構に興味を持ちイメージング 技術を使って研究を進めているが，ダイナミックに変 化し続けるシステムの一瞬を切り取り，その毫側に潜
むメカニズムを解明するには，全体としてのつながり を意識できるだけの，多くの知識を必要とすることを 改めて感じた，時には広い視野で，時には局所的な知 見をもとにして洞察することの大切さを今回の NISS2003 から学んだように思う。こうした研究への 取り組みがすぐにできるようになるとは思わないが, 少しでも近づくことができるように努力していきたい と思う。

最後に，このような機会を与えてくださったファカ ルティの方々と演習の時間を充実したものにするため に十分な準備をしてくださったチューターの方々に感 謝いたします。

\section{自分のサイエンス}

\section{東北大学 徳 永 太}

科学とは何か？そんな大それた問題に興味をもっ てから，数年が経つ、「科学」は英語の「science」の 訳語である.「science」の語源はラテン語の「知るこ と」だという。「知ること」に「科学」という訳語が あてられているのは,どうしたことであ万う？ 少々， 違和感がある。「科学」の出自には諸説あるらしい。 江厅期までの学問は明瞭な領域区分をもたなかった が, 明治期に伝わってきた西欧の学問は, 理科, 文科, 法科，医科，工科などと細かく分類されていた。「科」 に分類された「学」なので「科学」と訳された, 云々。 いずれにせよ，「科学」の出自は曖昧である。だから， 一部に混乱をきたす，例えば，「科学の暴走が医療不 信を招く」という。「科学」が「technology」あるい は「科学技術」という意味で使われる。こうした䛊謬 は「科学とは何か？」という問いを，より複雑にする。 以後,「科学」ではなく, 単に「サイエンス」と表記 する。

では，サイエンスとは何か？考察にうつる前に， サイエンスを「科学」以外の適当な日本語（雅語や漢 語）に置き換えよう。私は「知」がよいと思っている。 サイエンスの語源は「知ること」であった。だから， 「サイエンスとは何か？」は「知とは何か？」に帰着 される．知といえば知識である．しかし，知識だけが 知ではない. 知識体系の搪張や整備といった概念では 括れない何かが，知にはある.

以下は，とある臨済宗の㧍坊さんの括である．仏 道修行には三つの段階がある. 最初は, 経典を読んだ り，師匠の教えを聞いたりする。つまり「学」である.
しかし，読んだり，聞いたりするだけでは駄目で，そ の内容を暗記しなければならない。これが「覚」であ る.ところが，暗記するだけでも不十分で，さらに上 の段階を目指す，それが「悟」である，棓んじた経典 や教えを反罚するうちに，人は真理を悟る。「どの世 界でもそうでしょう.学んでいる間は半人前なんです」 と，御坊は笑われる，抒歳が自分とあまり変わらなか ったせいか,不思議と別世界の話には聞こえなかった。 日本の寺院にも古くからサイエンスが存在したなどと 主張すれば，たちまち変人扱いされそうだ。しかし， 本当にサイエンスは西欧に固有の営みだろうか？ サ イエンスを知と訳すことで，実は，そうでもなさそう だということがみえてくる，サイエンスを探すから大 変なのであって，知を探すのならそうでもない，例え ば，仏門をみよう。この国では，ながらく僧侶が学問 を担ってきた。つまり，仏門が知の場であった。ここ で醸成された東洋の知が, 西洋の开イエンスと何らか の相似性をもっていたとしても不思議はない，共に人 間たちのしてきたことである。御坊の括話を基に， 「学」「覚」「悟」の三位のなす環を知と定義しょう. まず, いかなる研究者も, 今日までに明らかにされて きた事実や問題点を知らなければならない。これが 「学」である、そして，それら事実や問題点をすべて 頭にいれる。これは「覚」だ。さらに，実験や観測， 調查, シミュレーションなどの実証を経て, それら事 実や問題点への新たな解釈や理解を提示する.これが 「悟」である。

優れた実証が，ほほ必ずといってよいほど，新たな 